\title{
NOTES
}

\section{ROBINSON-PATMAN CURTAILMENTS ON DISTRIBUTION INNOVATION: A STATUS SOUGHT FOR FUNCTIONAL DISCOUNTS*}

THE increasingly complex character of American economy has created powerful incentives for new methods of distribution and marketing. ${ }^{1}$ First, as costs of distribution become a more significant part of total costs, producers seek the economic advantages of more efficient distributive methods. ${ }^{2}$ In other instances, new marketing techniques-combining distributive services with the supply of goods-have become important competitive devices. ${ }^{3}$ Since many of the new methods adopted are, on their face, similar to those used to establish monopolies or other market controlling combinations, it has been difficult to determine whether an attempted change in market structure would benefit consumers by lowering distribution costs or harm them by obstructing competition. In addition, substantial policy considerations have been advanced in opposition to any change which harms small competitors, even though the harm they suffer might be attributed to their inability to improve their own efficiency. To accommodate these goals-seeking greater efficiency, protecting

*General Foods Corp., FTC Dkt. 6018 (Feb. 15, 1956).

1. Higher costs of distribution would appear to be a natural concomitant of technological improvement and higher standards of life. Urbanization, specialization and desire for variety seem to be the principal direct causes of these increased costs. TWENTIETH Centuruy Fund, Does Distribution Cost Too Much? 8-21, 292-97 (1939). Nor has distribution kept up with the technological advances which have occurred in production. $I d$. at 123-26. For an account of a similar experience in England see Harr, Distributive TRADING 16-29 (1949).

2. See, c.g., Report of the Attorney Generai's National Committee to Study the ANTitrust Laws 129, 204 (1955) (hereinafter cited ATr'y Gen. ReP.); Hall, Distributive Tradiag 66-68, 106-10 (1949); Twentteth Century Fund, op. cit. supra note 1, at 81-100.

3. See text at notes $47-54$ infra.

4. The principal methods used have involved integration, voluntary chains (associations of retailers formed to concentrate their buying power), and often discriminatory pricing. See authorities cited note 2 supra. For discussion of the dual nature of integration, see DIrLAM \& Kand, FaIr Cosspetition 141-50 (1954); see also note 12 infra. The partly monopolistic character of voluntary chains is considered in HALL, DIsTRIBUtTVE Trading 109-14 (1949). The various uses of price discrimination are treated in Machlup, Characteristics and Types of Price Discrimination, in Business CoNCENTRATION AND Price Policy 397 (National Bureau of Economic Research ed. 1955). Se'e also Rowe, Price Discrimitation, Competition and Confusion, 60 YALE L.J. 929, 935-37 (1950).

5. The inability to meet competition is rarely admitted explicitly by the defenders of small business, even though, since their arguments are not based on a claim of efficiency, they would not necessarily be overturned by such an admission. In fact some of the meas- 
competitors, and preserving competition-Congress enacted the RobinsonPatman Act, but instead of resolving these conflicts the act seems only to have added questions concerning its meaning. ${ }^{6}$

The problems engendered in establishing new methods of distribution are exemplified by the present controversy over "functional discounts"-price differentials granted by a seller as a result of the buyer's role in the distributive process. Although their desirability had been much debated in Congress, the Robinson-Patman Act made no specific mention of functional discounts, ${ }^{7}$ and its general provisions left their legality in doubt. ${ }^{8}$ The Federal Trade Commission, however, soon found a place for what might be called the "status" or "trade" type of functional discounts." It allowed a seller to establish a separate

ures taken in support of smallness can be justified only by considering efficiency less important than smallness. Twentieth CENTURY FuND, op. cit. supra note 1, at 253 (discussing chain store taxes). For the arguments made in favor of the small dealer see Bruce's Juices v. American Can Co., 330 U.S. 743, 765 (1947) (dissenting opinion); Automatic Canteen v. FTC, 346 U.S. 61, 82 (1953) (dissenting opinion) ; Doubleday \& Co., CCH Trade Reg. Rep. 1954-55 Transfer Binder If 25634, at 35680 (FTC 1955) (concurring opinion); Kaplan, SMall Business: Its Place and Problems 2-7 (1948); Comment, 66 YALE L.J. 69 (1956). For the view that efficient distribution is of paramount importance even if it be realized at the risk of small competitors, see Hall, Distriburive Trading 188-92 (1949) ; Twentieth Century Fund, op. cit. supra note 1, at 343-46, 363.

6. 49 STAT. 1526 (1936), 15 U.S.C. $\$ 13$ (1952). For different views on the history of the act and what it tried to accomplish see, e.g., Freer, Introduction to Section 2, in CCH Robrnson-Patnyan Act Symposium-1946, at 5 (1946) (to aid the "little man" but also to promote competition); Adelman, The Consistency of the Robinson-Patman Act, 6 Stan. L. Rev. 3 (1953) (to inhibit competition and discriminate against low-cost buyers-nothing but a re-enacted NRA); Oppenheim, Federal Antitrust Legislation: Guideposts to a Revised National Antitrust Policy, 50 MICr. L. Rev. 1139, 1199 (1952) (to preserve competition generally, but also for protection of competitors); ATr'Y GEN. REP. 129-31; Rowe, Price Differentials and Product Differentiation, 66 YALE L.J. 1, 2-3 nn.5, 6, 7, 34-36 nn.141, 142 (1956) and authorities cited therein. On the difficulties in ascertaining the meaning of the law see Ruberoid Co. v. FTC, 189 F.2d 893, 894-95 (2d Cir. 1951); Ruberoid Co. v. FTC, 343 U.S. 470, 492 (1952) (dissenting opinion) ; Automatic Canteen v. FTC, 346 U.S. 61, 65 (1953) (dictum). For the predictions made at the time the act was passed, see authorities cited in Comment, 54 Mrcr. L. Rev. 659, 668 n.42 (1956), and in Rowe, Price Discrimination, Competition and Confusion, 60 Yale L.J. $929,931 \cdot$.n.10 (1950).

7. The bill as originally passed by the Senate contained a provision allowing price differentials based on the position of the buyer in the distributive hierarchy. 80 Conc. REc. 6428 (1936). As reported out of committee, the House bill had a similar provision but distributive status was to depend on the nature of the selling of the party receiving the discount. H.R. REP. No. 2287, 74th Cong., 2d Sess. 1-9 (1936). Opposition by farm groups who feared for the status of farm co-operatives under these provisions apparently led to their removal. Comment, 54 Mich. L. REv. 659, 667 (1956); Shniderman, The Tyraminy of Labels, 60 HARv. L. REv. 571, 583-86 (1947).

8. Comment, 54 MICH. L. Rev. 659, 667-68 (1956); Shniderman, The Tyranny of Labels, 60 HaRv. L. Rev. 571, 580-87 (1947); Van Cise, Functional Prices, in CCH Robinson-Pataran Act Syarosium-1947, at 89, 91 (1947); Note, 56 Colum. L. Rev. 626-27 (1956).

9. "Status" functional discounts are here used to refer to discounts given solely because of a distributor's position in the distributive hierarchy, his position being defined by 
discount for each class of distributor buying from him, but a class was defined to embrace all distributors who competed against each other in reselling the discounted product. Thus, a vertically integrated wholesaler-retailer would be eligible for only the retail discount, since despite his performance of both functions he actually sold in competition with other retailers. ${ }^{10}$ These functional discounts based on status were thought to be consistent with the act for two reasons: they could not harm competition, since each distributor could receive no more than the discount given his competitors; and, since they were not explicitly forbidden by the act, they were permissible means of preserving traditional methods of distribution. 11 Thus, apart from the fact that, as permitted, status discounts themselves discouraged vertical integration of distributors as a method of increasing efficiency, ${ }^{12}$ the rationale in allowing them revealed a

the market in which he sells. The term is distinguished from "service" type of functional discounts, the size of which would depend on the services performed by the distributor receiving the discount. See Kelley, Functional Disconnts Under the Robinson-Patman Act, 40 Calif. L. Rev. 526 (1952) ; Van Cise, Functional Prices, in CCH RobinsonPatman Act Symposium-1947, at 89, 89-90 (1947) ; Note, 67 Harv. L. Rev. 294 (1953).

10. Standard Oil Co., 41 F.T.C. 263 (1945), modified, 43 F.T.C. 56 (1946), aff'd, 173 F.2d 210 (7th Cir. 1949), rev'd on other grounds, 340 U.S. 231. (1951), reissned with new findings, 49 F.T.C. 923 (1953), set aside, 233 F.2d 649 (7th Cir. 1956), cert. filed, 25 U.S.L. WeEk 3107 (U.S. Oct. 28, 1956) (No. 465) ; Sherwin-Williams Co., 36 F.T.C. 25, 64-66, 73 (1943) (holding that a wholesaler's discount could be received on that part of the produce sold at wholesale, but that merely taking the word of the jobber for the proportion so re-sold was not sufficient); Albert L. Whiting, 26 F.T.C. 312 (1938) (illegal to give greater discounts to one distributor than to others with whom he competed in selling). Such discounts, of course, might have been justified under one of the exceptions to $\$ 2$ (a) of the act, such as the cost justification. But see note 19 infra. The rule that the character of the selling was the significant factor, in part stemmed from the legislative origin of the act, see note 7 supra, but in part antedated the Robinson-Patman Act, comfurc The Mennen Co., 4 F.T.C. 258 (1922), with Mennen Co. v. FTC, 288 Fed. 774 (2d Cir.), cort. denicd, 262 U.S. 759 (1923). In other cases it was established that equal prices to those who did not sell on the same level in the distributive hierarchy were not discriminatory. Bird and Son, Inc., 25 F.T.C. 548, 552 (1937). But cf. Kraft-Phenix Cheese Corp., 25 F.T.C. 537, 540 (1937) (suggesting that retailers purchasing directly from the producer may actually be receiving discriminatory discounts, since other retailers, purchasing from wholesalers at a higher price, might nevertheless be purchasers from the producer within the meaning of the act).

11. Doubleday \& Co., CCH Trade Reg. Rep. 1954-55 Transfer Binder If 25634, at 35678 (FTC 1955); Van Cise, Functional Prices, in CCH Robinson-Patman ACT Symposium-1947, at 89, 92 (1947) (collecting cases). But see Kelley, Functional Discounts Under the Kobinson-Patman Act, to CALIF. L. Rev. 526, 530-32 (1952). Such discounts were permitted under the old Clayton Act since there was no competition between parties receiving different discounts. Mennen Co. v. FTC, 288 Fed. 774 (2d Cir.), cert. denied, 262 U.S. 759 (1923) : Baran v. Goodyear Tire \& Rubber Co., 256 Fed. 571, 574 (S.D.N.Y. 1919). For historical accounts of the judicial treatment of functional discounts, see Comments, 54 Mrce. L. Rev. 659 (1956) ; 49 Mrch. L. Rev. 261 (1950).

12. Clearly all cost saving inducement to integration would be destroyed if a distributor who performed retail and wholesale functions were charged the same price as one who performed merely retail functions. E.g., ATT'Y GEN. REP. 207-09; Note, 67 HaRv. L. Kev. 294 (1953); Adelman, The Consistency of the Robinson-Patman Act, 6 Stan. L. 
bias against any departure from traditional methods, however efficient such innovation might be.

The recent case of General Foods illustrates both the continuing attempt to improve upon traditional methods of distribution and the obstacles the Robinson-Patman Act may place in the path of innovation. ${ }^{13}$ General Foods had contracted to distribute some of its products through numerous small Institutional Contract Wagon Distributors (ICWD's) who admittedly competed against conventional wholesalers for the feeding institution business. ${ }^{14}$ General Foods agreed to grant ICWD's a discount from its wholesale list price in exchange for their undertaking to perform services not normally performed by wholesalers. ${ }^{15}$ The importance in terms of increased sales and consumer satisfaction

REv. 3, 13 (1953). It does not follow, however, that integration for predatory purposes would likewise be discouraged. Vertical integration may lead to lower costs and more efficient production, Comment, 19 U. CHI. L. Rev. 583, $611 \mathrm{n} .173$ (1952). It has been attacked, however, as a weapon in establishing a monopoly. DiRLAMr \& KAHN, FAIR ConsPETITION 22-23 (1954). Classically, a producer or distributor will integrate if the costs of the combined business plus implicit interest charges-i.e., the profit that would have been earned had the capital been otherwise invested-are lower than the costs plus implicit interest on the smaller capital base after paying an independent contractor to do part of the work. See Adelman, Integration and Antitrust Policy, 63 HARv. L. REv. 27, 33 (1949); Moore, The Automobile Industry, in StRucture of AMERICAN Industry 274, 297-99 (Adams rev. ed. 1954). In a fluctuating market, producers and middlemen may also integrate to stabilize their supply of essential materials or the demand for their products. This, in the long run at least, also results in cost savings. See McIsaac, The Cotton Textile Industry, in Structure of American Industry 47, 51-54 (Adams rev. ed. 1954). On the other hand integration may be undertaken merely as a means of acquiring a stranglehold on the market, either through control of a critical area of production or distribution or through the amassing of economic power. DirLAMs \& KAHN, FAIR CoMrPETITION 141-50 (1954); Standard Oil v. United States, 221. U.S. 1 (1911); see also Dirlam, The Petroleum Industry, in Structure of American Industry 236, 266-69 (Adams rev. ed. 1954). But see Bork, Vertical Integration and the Sherman Act, 22 U. Cur. L. REv. 157,194201 (1954). While it is sometimes said that the cost advantages of integration are only with difficulty separated from its more predatory uses, see, e.g., DiRLAN \& KaHN, FaIR Competrtron 151 (1954), a law which would hinder all integration would not appear justified. Accordingly the Supreme Court has refused to hold integration illegal per se under the Sherman Act. United States v. Columbia Steel Co., 334 U.S. 495, 525 (1948); United States v. Paramount Pictures, Inc., 334 U.S. 131, 174 (1948). For excellent treatment of the problems and misconceptions arising from integration and the antitrust laws see Bork, supra (analyzing cases and destroying many arguments made against integration as a weapon of monopoly); Comment, 19 U. CHI. L. Rev. 583 (1952) (collecting authorities, analyzing cases, and examining the economics of integration). See also Kelley, Functional Discounts Under the Robinson-Patman Act, 40 CALIF. L. REv. 526, 529 (1952) (cost justification defense under $\$ 2(a)$ is more difficult for integrated distributors than for independents, since "normal profits" are not allowed as a cost).

13. FTC Dkt. 6018 (Feb. 15, 1956), adopting Initial Decision (Mar. 22, 1955).

14. FTC decision at 3.

15. The contract provided that ICWD's should: sell aggressively, provide door to store delivery, offer services offered by competitors, maintain adequate stocks, arrange to move older stocks first, handle damaged merchandise in accord with General Foods policy, distribute promotional materials, maintain replacement parts for coffee-making equipment, 
of selling in the ICWD manner was not denied. ${ }^{16}$ Although the reasonableness of the discounts was neither proved nor disproved, part of the Commission's reasoning may justify an inference that they were not excessive. ${ }^{17}$ Nevertheless, the Federal Trade Commission held that the discounts were a violation of section 2(a) of the Robinson-Patman Act, and that they were not within any exceptions to section 2 (a) which section 2 (d), as interpreted, may create. ${ }^{18}$

Three years ago, the General Foods holding would have been no surprise. It was generally thought at the time that service-type functional discounts could be justified, if at all, only as promotional services under section 2 (d)..$^{19}$

arrange for proper displays of products in public feeding establishments, make deliveries, for extra pay, on General Foods sales to multiple food operators. Id. at 2-3. See also Initial Decision at 7-8.

16. Initial Decision at 8,10 .

17. In a separate count the government argued that General Foods' payments to ICWD's for their delivering food sold directly by General Foods were so grossly excessive that they constituted hidden discounts to the ICWD's as purchasers. Although delivery was of course less valuable a service than sale and delivery, and the payments for delivery alone were equal to, and in the case of coffee $50 \%$ more than, the payments for both, the Commission affirmed the hearing examiner's finding that the payments were not grossly excessive. Initial Decision at 14-16, adopted by FTC at 10.

18. FTC decision at 4-7.

19. Van Cise, Finctional prices, in CCH Robinson-Pataran Act Sympostun1947, at 89, 91 (1947); Note, 56 Coluar. L. REv. 626, 627-28 (1956). This of course assumes that they could not be justified under one of the specific exceptions to $\S 2(a)$ : the cost justification, good faith meeting of competition, or the changing conditions defenses. See Robinson-Patman Act, 49 Stat. 1526 \& 2(a) (b) (1936), 15 U.S.C. § 13(a) (b) (1952). Of these three only the cost justification defense could be generally applicable as a way of saving functional discounts. It allows differentials "which make only due allowance for differences in the cost of manufacture, sale, or delivery resulting from the differing methods or quantities in which such commodities are to such purchasers sold or delivered." Ibid. Thus the cost defense, if feasible, seems to protect service functional discounts, Edwards, Maintarning Competition 161 (1949), but strict reading and the enormous cost of preparing and presenting a cost defense, as well as the elusiveness of cost data, have made this defense almost useless. Automatic Canteen Co. v. FTC, 346 U.S. 61, 68, 79 (1953) ; ATT'y GEN. REP. 170-76 (collecting cases). See particularly the full discussion and compilation of authorities on the cost defense in Rowe, Price Differentials and Product Differentiation, 66 Y ALE L.J. 1, 21-23 nn.91-100, 43-45 nn.168-73 (1956). For an additional obstacle to a successful cost justification, see Kelley, Functional Disconnts Under the Robinson-Patman Act, 40 CALIF. L. REv. 526, 528 (1952) (seller's cost does not include implicit interest charges on his investment; thus seller can not show that the'se charges decrease when his purchaser, by backward vertical integration, undertakes greater functions).

Although $\S 2$ (a) prohibitions apply only to price discriminations which may substantially lessen competition, this limitation will currently shelter few service functional discounts. The courts have held a price differential, at least among competitors, to be prima facie evidence of lessening of competition, but this rule has not been followed consistently and is currently subject to vigorous attack. For review of the many problems raised by the lessening of competition doctrine and analysis of cases, see, e.g., ATT'Y GEN. Rer. 160-70 (1955) (attacking prima facie rule); Rowe, Borderland Issues in Court and Commission Cases Under Sections 2 and 3 of the Clayton Act, in ABA Section of ANTItrust Law Procendings 60 (April 1956) (same). 
But even this possible loophole offered virtually no hope. Traditionally payments for promotional services made under section 2(d) were limited by several strict requirements : they could be made only for services not merely contracted for, but actually performed: and each payment had to be reasonably related to the value of the service, determined by objective standards. ${ }^{20}$ Clearly the services involved in General Foods could not qualify, and the Commission so held. General Foods agreed to grant a discount in return for a promise of services and, the Commission noted, did not police its contracts to insure that the ICIVD's performed. ${ }^{21}$ Moreover, although some ICWD's rendered greater services than others, all received the same discount; the payments, consequently, could not have been reasonably related to the services performed, at least in a strict sense. Mlore important, the services promised were, by their nature, not susceptible of definite valuation.2

Coming when it did, however, General Foods represented a significant departure from the course the Federal Trade Commission had been expected to follow. Recently the Commission seemed to have accepted the recommendation of the Report of the Attorney General's National Committee to Study the Antitrust Laws: the legality of functional discounts should no longer be based solely on the re-sale functions performed by a distributor, but as well on the services-transportation and storage, for example-which the distributor renders. ${ }^{23}$ In the Doubleday case, the Commission, by a three to two margin, admitted evidence proffered to show that discounts given to distributors who resold in the retail market were given as payment for services rendered by them as jobbers. ${ }^{24}$ Although the FTC found that the payments were in fact price reductions in violation of section 2(a) and not payments for jobbing services, ${ }^{25}$ it not only admitted the evidence but also explicitly approved the theory on which it was offered: differing discounts to competing distributors were not violations of section 2(a) if reasonably related to the value of

20. FTC decision at 5-6; Dunn, Section 2(d) and (e), in CCH Robinson-Patmav Acr Symposium-1946, at 55, 65-66 (1946) : Lever Brothers Co., FTC Dkt. 5585 (1954): Procter \& Gamble Distributing Co., FTC Dkt. 5586 (1954) ; Colgate-Palmolive-Peet Co.. FTC Dkt. 5587 (1954). The above opinions are digested in $1 \mathrm{CCH}$ TRAnE REg. RaP. Iก $3522.530,3522.650$.

21. FTC decision at 6 .

22. Ibid.

23. See Doubleday \& Co., CCH TRADE REg. REP. 1954-55 Transfer Binder $\{255,34$ (FTC 1955) (relying heavily on the very language in ATT'Y GEx. REP. at 202-08). The report in turn attempts to rely on the "mandate," given by various Supreme Court opinions, to recognize actual marketing functions "rather than ambiguous labels." AтT'Y GEN. REP. 208-09 (citing FTC v. Ruberoid Co., 343 U.S. 470, 475 (1952) ; Times-Picayunc Publishing Co. v. United States, 345 U.S. 594, 615 (1953); United States v. Masonite Corp., 316 U.S. 265, 280 (1942) ; FTC v. Motion Pictures Advertising Serv. Co., 344 U.S. 392, 397 (1953) ; Standard Oil Co. v. FTC, 340 U.S. 231, 236 n.4 (1951)).

For indications of the significance ascribed to Doubleday, see, e.g., Comment, $54 \mathrm{MICH}$. L. Rev. 659, 673-80 (1956) ; Note, 56 Cor.uM. L. Rer. 626 (1956).

24. Doubleday \& Co., supra note 23 , at 35678.

25. Id. at 35679 . 
those distributive functions actually performed by them. ${ }^{26}$ Thus, in a major turnabout, the Commission clearly indicated that to a "status" theory of functional discounts had been added a "payment for services performed" or "functional" theory, and that service-type functional discounts could be granted protection under the Robinson-Patman Act without being justified under one of the explicit exceptions to section 2 (a).27

Commentators have disagreed on the impact of General Foods on Doubleday. 28 In Gencral Foods the defendant attempted to meet the charge of a section 2 (a) violation by justifying the discounts under section $2(\mathrm{~d}){ }^{29}$ The FTC rejected the defense, stating that section $2(\mathrm{~d})$ requirements had not been met and that the discounts were not of a character generally covered by section 2(d). ${ }^{30}$ The Commission then considered, separately, whether General Foods had made proper payments for functional discounts under section 2 (a); on this issue as well it found against the defendant, stating that the discounts must accord with the "terms and conditions" of section $2(\mathrm{~d}) .^{\mathbf{3 1}}$

On this latter issue, the two cases can be reconciled. In both cases, the FTC was willing to consider the possibility that service-type functional discounts night be legal under section 2(a). In Doubleday, the Commission listed cer-

26. Id. at $35677-78$. Two of the commissioners rejected the majority rationale in concurring opinions. Commissioner Mead, apparently unconvinced by the authorities gathered by the Report of the Attorney General's Committee, see note 23 supra, noted: "whether or not this is good economics, I am not prepared to say .... [I]t is not the law as expressed in the Robinson-Patman Act." Doubleday \& Co., CCH Trade Reg. Rep. 1954-55 Transfer Binder $\{$ 25634, at 35680 (FTC 1955).

27. Comment, 54 Mich. L. Rev. 659, 678 (1956); Note, 56 Colum. L. Rev. 626 (1956); Rowe, Borderland Issues in Contr and Commission Cases Under Sections 2 and 3 of the Clayton Act, in ABA Section of Antitrust Law Proceedings 60 (April 1956). In adopting this theory the Commission noted certain requirements including a reasonable relation between the amounts of the discounts and the services furnished, Doubleday \& Co., supra note 26 , at 35678 ; and probably, according to one commentator, that the discounts must be made available on equal terms to all, Note, 56 CoLUM. L. Rev. 626, 629 (1956). The latter is probably a reasonable restriction. See text at note 58 infra. If the reasonable relation rule is interpreted to require comparison of the discount with an exact valuation of the service, the seller would probably need to establish a causal relationship between an increase in his profit and the distributor's service. This "profit justification" would pose the same ubstacles to service functional discounts as the cost justification defense, see note 19 supra.

28. Comment, 54 MICH. L. REv. 659, 678 n.75a (1956) (General Foods is perfectly consistent with Doubleday, since General Foods did not insure that the ICWD's actually rendered the services promised); Rowe, Borderland Issues in Court and Commission Cases Under Sections 2 and 3 of the Clayton Act, in ABA SeCtion of Antrtrust Law Procennings 60 (April 1956) (General Foods "obliterates all trace of the Doubleday de(ision").

29. FTC decision at 4,6 .

30. Id. at 4-6. In holding that these could not be $\$ 2$ (d) payments the Commission also cited Champion Spark Plug Co., FTC Dkt. 3977 (1953), opinion digested $1 \mathrm{CCH}$ Trune REG. REP. $\Uparrow 3522.360$, which held that $\$ 2$ (d) covered only payments, not discounts.

31. FTC decision at 6-7. 
tain requirements which service-type functional discounts would have to meet; these standards resemble some traditional section $2(\mathrm{~d})$ requirements. ${ }^{32}$ By reading the section 2 (d) "terms and conditions" into the 2 (a) context, the FTC in General Foods may have meant to overrule Doubleday. But if the Commission meant only those conditions it had stated in Doubleday, the cases are consistent. If the Commission meant either all section 2(d) requirements or more than were listed in Doubleday-including the prerequisite that discounts be offered to competitors on "proportionally equal" terms-the cases can still be reconciled. Doubleday involved traditional distribution services; General Foods involved entirely new distributive methods. ${ }^{33}$ The FTC then may have indicated it would adhere to stricter standards for new methods. ${ }^{34}$ In addition, it may have felt that the requirements of section $2(\mathrm{~d})$ incorporated into section 2(a) could be met in Doubleday, but not in General Foods. For example, if it can be inferred that the prohibition against services of uncertain value is picked up by section 2(a), the Doubleday services must be deemed more susceptible of objective valuation than the General Foods services because Doubleday services were the same as those traditionally performed by the independent wholesalers, jobbers and retailers long protected under section $2(\mathrm{a}) .^{\mathbf{3 5}}$ And the same reasoning can be applied to other section $2(d)$ requirements which depend at least in part upon an acceptable valuation-actual performance of the services and a reasonable relationship between performance and payment. ${ }^{36}$

32. Doubleday \& Co., CCH Trade Reg. ReP. 1954-55 Transfer Binder If 25634, at 35678 (FTC 1955) (implying that in some form the "reasonable relation" and "actual performance" tests would have to be met). There was no direct mention, however, of a requirement of an exact price tag or that the payments must be offered on "proportionally equal" terms to all. More important, perhaps, there was no indication that such requirements would be interpreted in their strict, technical $\$ 2$ (d) meaning.

33. Doubleday \& Co., supra note 32, at 35677-78. The discounts in Doubleday, unlike those in General Foods, were for services by integrated distributors. In particular, the services which the recipients of discounts in Doubleday were said to have performed were merely those resulting from the union of the traditional jobbing and wholesaling functions in the book industry. Ibid. In General Foods, on the other hand, the services performed were entirely new, and did not merely constitute the performance of the services of two previous classes by one new class. FTC decision at 2.

34. I.e., when traditional services are performed, though by integrated distributors, a proper service functional discount can be granted, but when new services are performed the payments are ruled by $\S 2$ (d).

35. This fact, however, does not of itself make the Doubleday services easier to value. It is not at all clear that all integrated jobbers would perform their functions in the same way or to the same extent. Nor could the benefit of such services to the seller be given a simple price tag. Had this been so, the cost justification would have been a more valuable defense in pre-Doubleday situations than it in fact was. See notes 19, 27 supra. Thus the only way in which Doubleday services could be valued more easily than Gencral Foods services would be by analogy with the price of these same services when performed by independents.

36. Actual performance could well be interpreted to mean that each distributor must give full value for the discounts paid him. In addition, since unperformed promises will not justify discounts, FTC decision at 5-6, the requirement that the discount must be re- 
The conclusion that Doubleday was not overruled derives support from the fact that the General Foods opinion was written by a member of the Doubleday majority, Chairman Gwynne, and the only other member of that majority who sat on both cases, Commissioner Mason, did not dissent. ${ }^{37}$ Thus the Commission may have chosen a middle course. It may still be willing, as in Doubleday, to consider service-type functional discounts as having a separate status under section 2(a) of the act but since service-type functional discounts are not specifically exempted from the prohibitions of section 2(a), the Commission will accord them protected status only if they meet strict standards derived from section 2(d). Applying section 2(d)'s standards, as construed in General Foods, however, has one clear result: payments for services which traditionally were performed by wholesalers, retailers or other established classes of distributors are strongly preferred over payments for new services.

Although the result in General Foods may protect independent wholesalers from new methods of distribution, it has serious disadvantages in terms both of protecting consumers and of promoting competition among producers. It might be argued, that those institutional users who buy from conventional wholesalers and the ICWD's, should be free to choose between buying both food and the ICWD service and buying the food alone at a lower price, for only this free market action can demonstrate whether the ICWD innovation is desirable. ${ }^{38}$ This argument has little validity. It assumes that General Foods could either cut its prices generally, allowing the ICWD's to sell their services with the product at the list price before the cut: or maintain the current price, giving consumers an option to buy ICWD services for an additional consideration. However, a general price cut is seldom feasible in oligopolistic situations. ${ }^{39}$

lated to the service really means reasonably related to the value of the performance, and value, again, may mean value objectively determined, see note 27 supra.

37. FTC decision at 1; Doubleday \& Co., CCH Trade REg. Rep. 1954-55 Transfer Binder If 25634, at 35676 (FTC 1955). That Doubleday was not overruled is further indicated by the Commission's last statement under this count "to hold that the rendering of special services ipso facto gives him a special functional classification would be to read Section 2(d) out of the Act." FTC decision at 7. The use of the words "ipso facto" implies that special services of a particular kind, or which meet some of the requirements of $\S 2(d)$, could still be in a protected status. That the position taken in Doubleday was in fact the majority view, despite Commissioner Gwynne's ambiguous concurrence, is seen at Doubleday \& Co., supra at 35676, and in Commissioner Mead's concurrence where it is expressly termed "the position of the Majority," id. at 35680.

38. See Initial Decision at 11.

39. Galbraith, Monopoly and the Concentration of Economic Pozer, in 1 Ax. Econ. Ass'n, A Survey of Contemporary Economics 113 (Ellis ed. 1949); Rothschild, Price Theory and Oligopoly, 57 Econ. J. 299 (1947), reprinted in AMr. Econ. Ass's, Readings in Price Theory 440, 455-57 (1953) ; Sweezy, Demand Under Conditions of Oligopoly, 47 J. Pol. Econ. 568 (1939), reprinted in id. at 404, 408; see also Fellner, CoMretimion Among the FEw 182-83 (1949) (price cut likely only if oligopolist either desires to test opponent's strength or desires a price war); Rowe, Price Differentials and Product Diffcrentiation, 66 YALE L.J. 1, 31-32 (1956). But see Stigler, The Kinky Oligopoly Demand Curve and Rigid Prices, 55 J. PoL. ECoN. 432 (1947). 
Were General Foods to offer its food at a lower price to its consumers, its competitors would probably follow, and might even take General Foods' cut to be a signal for a price war and undercut. ${ }^{40}$ In many cases the demand for the products of the industry as a whole will not be sufficiently elastic to enable General Foods to profit by a price cut which is matched; in any event, the fear that a price war will follow nearly always outweighs this limited hope of profit. ${ }^{41}$ And even if price cuts were feasible, only General Foods was in a position to, and apparently did. foresee the cost reduction advantages of the new service. For even after a price cut consumers would assumedly be offered the service at a price sufficiently above the price of the goods alone to cover the high initial cost of offering the service. Under such circumstances there is no reason to assume that consumers would purchase the new service in sufficient quantity to permit any economies of scale in the service itself. ${ }^{42} \mathrm{~A}$ consumer option to pay for the new service plus the current price for General Foods' products would have the same defect. In addition, since consumers would have to pay more for the product-service combination, the option plan would be less likely to induce greater sales and realize the lower production costs of increased output. And because any efficiencies from greater output that might result would inure only to General Foods, the consumer would receive none of the benefits of these efficiencies. In contrast, under the plan struck: down in General Foods, the consumer was actually receiving the services without any increase in price. ${ }^{43}$

The effect of General Foods is to hinder an effective and desirable method of competition which is, indeed, often the only one available to producers.

40. FELLNER, op. cit. supra note 39, at 182; Rothschild, supra note 39, at 457; Sweezy, supra note 39 , at 405 .

41. See Rowe, Price Differentials and Product Differentiation, 66 YALE L.J. 1, 32 (1956). In a recent series of essays on various American industries all of the authors who considered the elasticity of demand for their industry found either that the industry demand was inelastic or that members of the industry were strongly convinced it was inelastic. In one case an estimate of elasticity indicated it might be slightly greater than one, but neither the industry nor the author thought this was elastic enough to warrant a price cut. Adams, Structure of American Industry 20-21 (agriculture), 308-09 (automobiles), 212-13 (chemical), 336-38 (cigarettes), 254 (petroleum), 175-77 (steel) (rev. ed. 1954). See also Rothschild, supra note 39 , at 460 (oligopolists always consider possibility of price war when making decisions); FELLNER, op. cit. supra note 39, at 179, 182 (desire to avoid cutthroat competition causes deviations from course which would maximize the joint profits of the industry).

42. In many cases the cost of services will be less than their value to purchasers only if they are sold in volume. Thus they can be offered only if General Foods is permitted to bear part of their cost until sufficient demand is developed. Evergreen Amusement Corp. v. Milstead, $206 \mathrm{Md}$. 610, 621, 112 A.2d 901, 906 (1955) (admitting the need for time in which to develop demand). Samiunison, Economics 393-94 \& n.1 (3d ed. 1955) (discussing reversible and irreversible economies of scale, both internal and external to the firm).

43. Since few new services will be popular enough to establish themselves at the 
Since the price in an oligopolistic market structure, a highly common situation in our economy, ${ }^{44}$ is a resultant of an unspoken compromise of the policies and desires of the several members of the industry, ${ }^{45}$ a single producer may find that the quantity he can sell at this price is less than the quantity which would maximize his profit. ${ }^{4 b}$ Apart from openly cutting prices, a step he fears to talse, ${ }^{47}$ the producer can increase his sales by: $A$, product differentiation or improvement; $B$, hidden, and since hidden usually discriminatory, price cuts; and $C$, payments for services, often new services, offered, as in General Foods. ${ }^{48}$

relatively high initial cost, producers who desire to increase output will often be the only ones willing to bear part of their cost, and thus in effect give a price cut, when no one would be willing to bear the risk of offering the service at cost. And even if the service were successfully offered at cost, the consumers will have received no benefit from any increase in output which resulted. Compare this with H.R. REP. No. 2287, 74th Cong., 2d Sess. 17 (1936), which noted that there is nothing in the Robinson-Patman Act which hinders efficiency and economies and that the act in no way infringes the seller's freedom to pass the benefits of such economies on to those with whom he deals. For reasons why General Foods might desire increased output even if it had to bear the costs of added service see text at notes $46-48$ infra.

44. FELLNER, op. cit. supra note 39 , at $18-23$ (not universal, but very frequent, particularly in manufacturing); Galbraith, supra note 39, at 101, 127 (dominant market form in our economy).

45. Felliver, op. cit. supra note 39 , at c. I, 175-82 (defining the quasi-agreement in oligopoly and discussing its effect on oligopolistic pricing); see Rothschild, supra note 39 , at 452-57.

46. See note 48 infra.

47. See notes 39,41 supra. This assumes that he is not in so desperate a situation that even a price war appears desirable to him.

48. For a treatment of the type of competitive moves likely in an oligopoly situation, see FelLANer, op. cit. supra note 39, at 183-91 (many dynamic changes are still possible in oligopolies); Clark, Toward a Concept of Workable Competition, 30 AMr. Econ. Rev. 241, 253 (1940) (on the existence of discriminatory "price chiselling" in oligopoly). In oligopoly the producer cannot base his price solely on cost and demand considerations, see authorities cited note $\mathbf{4 5}$ supra; indeed he has no demand function in the classical economic sense, see FELLNER, op. cit. supra note 39, at 3-15. Moreover, since he represents a substantial portion of the industry, and, ceteris paribus, the quantity sold by the industry depends on price, the individual producer cannot vary his own sales at the given price unless he uses one or more of the methods outlined in the text. Lacking full control of either price or output, he may not therefore be producing at the output which would maximize his profits. He then has a strong incentive to vary his output by using the methods outlined in the text, all of which may be equivalent to a price cut. This incentive may exist even though competitors would immediately follow, at least if the industry demand curve were elastic. In that case, industry revenues would be increased by the equivalent of a price cut which was, itself, unfeasible. The incentive may of course be heightened by the normal desire, present in other market structures, to achieve through advertising and services a constantly increasing demand for the industry products.

In pure competition, the producer cannot control price; forming an infinitely small part of the market, he can, however, sell whatever he wishes at the existing price. He will, therefore, regulate his output so that he produces at the profit-maximizing point. CHAMnerlin, The Theory of Monopolistic Competitron 16-21 (6th ed. 1951). His only incentive for undertaking one of the methods listed in text would be to differentiate his product and become an imperfect competitor. In pure monopoly the producer has control 
All these, even when discriminatory, are in effect sparks of competition in a generally noncompetitive area. ${ }^{40}$ The current interpretation of the RobinsonPatman Act seriously impedes method $A .{ }^{50}$ Moreover, from the standpoint of the consumer, it is questionable whether $A$ is preferable to the method adopted by General Foods.51 Method $B$, while at times urged by economists, is not only illegal but dangerous because it is often impossible to tell if hidden price cuts are used for competitive or predatory reasons. ${ }^{52}$ Method $C$ may, in some cases, be less desirable than an open price cut, ${ }^{53}$ but $C$ is the closest approach to an open price cut an oligopolistic quasi-agreement will permit; and $C$ is permitted because, unlike a price cut, its danger to the industry is limited and, more important, it is often essential to a method of competition popular with oligopolists-innovation. ${ }^{54}$ It may be true that the competition engendered by

of either price or output and may, therefore, always choose to produce at the profit maximization level. Boulding, Economic Analysis 523-33 (rev. ed. 1948). Hence, his only incentive for using the methods in text is a desire to shift the industry demand curve outward.

In monopolistic competition, the producer may also control either the price or the output of his product, and will produce at a point which maximizes his profits. Because of the large number of close competitors, however, he is likely to remain with excess capacity. He would then, more strongly than the monopolist, be motivated to shift his demand curve outward. Chamberlin, op. cit. supra at 70-100. But see Harrod, Theory of Imperfect Competition Revised, in Economic Essays 139 (1952) (arguing that such excess capacity equilibrium is unlikely).

49. Authorities cited note 48 supra; Edwards, MaIntaining Conrperition 167-68 (1949).

50. For a thorough treatment of this problem see Rowe, Price Differentials and Product Differentiation, 66 Y ALE L.J. 1 (1956).

51. When product differentiation takes the form of genuine differences in product-in which case it is very similar in effect to method $C$-it gives more to the consumer for the same amount of money. Rowe, Price Differentials and Product Differentiation, 66 YALE L.J. 1, 32-33 (1956). On the other hand, when it merely represents a difference in label, sold by much advertising, it is of doubtful value to the consumer. Brown, Advertising and the Public Interest, 57 Y ALE L.J. 1165, 1167-84 (1948). See also Atr'y GEN. REP. 15758, 330-31 (discussing, not altogether unfavorably, product differentiation).

52. Edwards, Maintaining Competirion 167-68 (1949) (suggesting that antipathy to competition in these areas usually takes the form of trying to prevent secret price concessions); Clark, supra note 48, at 253 (describing price chiselling as more competitive than fixed prices, and more workable than unlimited market chaos); Machlup, Characteristics and Types of Price Discrimination, in BusIness ConCentration AND PRICE PoLIcy 423-25. (National Bureau of Economic Research ed. 1955) (considering the difficulty in distinguishing the purposes of discriminatory pricing).

53. See text at notes 38-42 supra. Of course the consumers may be economically irrational; they may buy more of a given product if the service is offered "free" than when the product is sold at a price sufficiently low to enable the service to be bought at the same total cost. Another strong argument then exists for allowing the producer to bear the cost of the service whether a price cut is feasible or not.

54. FELLNER, op. cit. supra note 39 , at $183-91$ (noting that competition is often tacitly allowed in those variables, related closely to inventiveness, because of their limited danger, and because of the need to find outlets for changes in relative strength of the competing producers. A very mature, or cartellized, oligopoly might of course not even allow this much competition). 
introducing such "free services" is insufficient, and that all oligopolistic market structures should be condemned. ${ }^{55}$ Still, striking at whatever sparks of competition exist and leaving the evil, if such it is, ${ }^{56}$ untouched is surely no answer, ${ }^{67}$ especially since competition at the distributor level can be protected from the potentially discriminatory nature of such "free services."

Incorporating some of section 2(d)'s safeguards into section 2(a) will insure that no producer uses service functional discounts to prefer his favored purchasers over their competitors. A producer should be required to offer his functional discount to all competing distributors who are able and willing to perform the service for which the discount is given, at least after the service has been developed and tested. ${ }^{68}$ The producer should also be required to police his contracts to assure himself that each distributor substantially performs. And the discounts should be held invalid if it appears that they are not reasonably related to the value of the services or that the producer in fact did not attempt to fix their value in good faith. By these safeguards, distributors will be protected from bogus services and other unfair preferences. ${ }^{59}$

Applying all of section 2(d)'s requirements, as construed in prior cases, can be justified only by a desire to insulate distributors from the challenge of new methods of distribution. These requirements would invalidate nearly all service functional discounts, and certainly all those offered for new services. If a producer is required to grant functional discounts to distributors who can perform new and valuable services and equally to those who cannot perform, he is hardly likely to adopt a method of distribution, however efficient, based on that service. ${ }^{60}$ And to require that the producer determine the exact degree

55. National Lead Co. v. FTC, 227 F.2d 825, 834 (7th Cir. 1955), cert. granted, FTC v. National Lead Co., 351 U.S. 961 (1956), cert. denied, National Lead Co. v. FTC, 351 U.S. 964 (1956) (existence of other forms of competition does not justify lack of price competition); United States v. Socony-Vacuum Oil Co., 310 U.S. 150, 220 (1940) (same). See also American Tobacco Co. v. United States, 328 U.S. 781 (1946) (often interpreted as implying the illegality of oligopoly as a market structure).

56. For a defense of oligopolies see Schunpeter, CApItalism, Soctalism, and Dearocracy 81-106 (2d ed. 1947). For a middle of the road analysis see FeILNER, op. cit. stipra note 39 , at $282-311$.

57. Dirlaki \& Kaen, Farr Competimton 204-05 (1954); Edwards, Maintaining Competition 167-68 (1949); Clark, supra note 48, at 242, 253.

58. A manufacturer should not be forced to give up a tried system of distribution for a system which could give no assurance of success.

59. It is often stated that this was the only aim of $\S 2$ (d) and that it should be narrowly construed. See, e.g., Rowe, Price Differentials and Product Differentiation, 66 YALE L.J. 1, 25-26 n.112 (1956). But see id. at $26 \mathrm{n} .114$ (discussing the FTC's recent increase in activity under $\$ \$ 2(d),(e))$.

60. Yet in construing $\$ 2$ (d) in General Foods the Commission said "The services for which payment may be made under $\S 2$ (d) must be of such a character that they can be made available on proportionally equal terms to all customers." FTC decision at 5 . Similarly in Elizabeth Arden, Inc. v. FTC, 156 F.2d 132, 133 (2d Cir. 1946), cert. denied, 331 U.S. 806 (1947), it was held to be a violation of $\$ 2(\mathrm{e})$, which uses language similar to $\S 2$ (d), for Elizabeth Arden to offer demonstrator services tailored in such a way that only few customers who sold prestige products could qualify for it. The court further 
to which each distributor performs and then pro rate his discount accordingly would impose an oppressive administrative burden. Moreover, the section 2(d) requirement, announced in General Foods, that the service must be one on which an exact price tag can be put ${ }^{61}$ would invalidate all new services; and many old services will be similarly excluded unless their value when performed by new classes of distributors can be determined by analogy to their value when performed by traditional classes. ${ }^{62}$

The Federal Trade Commission and the courts should not interpret General Foods as overruling Doubleday, for only by reconciling the two cases can vertical integration among distributors be encouraged where it promotes efficiency. The middle ground, granting service functional discounts a protected status under section 2(a) provided some of the conditions of section 2(d) are met, is in itself sound. However, the prohibitions of section 2(d) should not be rigidly adhered to in applying the General Foods holding to future 2(a) cases involving genuine innovations in distribution. ${ }^{63}$ Construed as suggested, the sanctions of the Robinson-Patman Act will guard against unfair preferences without hampering competition among oligopolistic producers or impeding the development of more efficient methods of distribution.

ruled that the seller must furnish the service, if at all, so proportioned and under such terms that all competing purchasers might receive it. Id. at $135 \&$ n.6. In Elizabeth Arden Sales Corp. v. Gus Blass Co., 150 F.2d 988, 994-95 (8th Cir.), cert. denicd, 326 U.S. 773 (1945), the court granted treble damages under $\$ \S 2(d)$, (e) where furnishing demonstrators, or paying their salaries, dejended on individual negotiation and was not on a proportionally equal basis. The court cited with approval the FTC to the effect that "the furnishing of a service or facility which cannot be proportionalized for the benefit of competing purchasers ... constitutes a failure to accord such services or facilities upon proportionally equal terms." See also Dunn, Section 2(d) and (e), in CCH Robinson-Patman Act SYarposium-1946, at 55, 68-70 (1946) (accepting this strict reading of the rule of $\$ 2$ (d) and $\S 2(\mathrm{e})$ ) ; Montague, "Proportionally Equal Terms" in CCH RoBInson-PatanaN ACT Symposium-1948, at 51 (1948) (same). But see Lever Brothers Co., FTC Dht. 5585 (1954) (holding no violation merely because purchasers of smaller quantities cannot avail themselves of higher payments offered for newspaper advertising, since no favoritism was shown and all knew about the plans) ; Procter \& Gamble Distributing Co., FTC Dkt. 5586 (1954) (same) ; Colgate-Palmolive-Peet Co., FTC Dkt. 5587 (1954) (same) ; FTC Trade Practice Conference Rules for the Cosmetics Industry, $3 \mathrm{CCH}$ TrAdE REG. REP. If 20221 (1951).

61. FTC decision at 5. But cf. Lever Brothers Co., FTC Dkt. 5585 (1954) (requiring merely that payments be made in good faith for services actually rendered and that a fair and reasonable relation exist between the amount of payment and the type of service rendered) ; Procter \& Gamble Distributing Co., FTC Dkt. 5586 (1954) (same) ; ColgatePalmolive-Peet Co., FTC Dkt. 5587 (1954) (same).

62. See notes 35,36 supra.

63. In General Foods the fact that a different method of distribution was involved was generally admitted. FTC decision at 6 . The special status of ICWD's had, moreover, been recognized by the OPS in its determination of price ceilings. Initial Decision at 10. 